\title{
Sustainable Development of Real Estate Market and its Assessment Opportunities: Case Study of Latvia
}

\author{
Linda Kauškale ${ }^{1}$, Ineta Geipele ${ }^{2}$
}

\begin{abstract}
:
Nowadays, more and more attention is being paid to the country's economic development, for which sustainable development of real estate market is important. The topicality of the research is driven by variety of regulations, economic and environmental issues worldwide and the research has a high social, economic and environmental importance. The aim of the research is to analyse significant aspects of sustainable development of real estate market, and to make its assessment in Latvia. Questions that have a high importance for sustainable industry development were analysed in the research as well. Research methods include a combination of quantitative and qualitative research methods, such as analysis, synthesis, statistical data processing, focus group and expert questionnaire and other methods. The survey is focused sectors Construction and Real Estate Operations - primary on managers and employees of enterprises who are working in development of building projects, construction of residential and non-residential buildings, real estate agencies, management of real estate on a fee or contract basis, renting and operating of own or leased real estate, buying and selling of own real estate. Theoretical overview includes world and European experience on the research question and the related problems. The research includes integrated approach of assessment of the real estate market.
\end{abstract}

Key words: Assessment, case study, Latvia, real estate market, sustainable development

\section{Introduction}

The aim of the research is to analyse significant aspects of sustainable development of real estate market, and to make its assessment in Latvia. Questions that have a high importance for sustainable industry development were analysed in the research as well. Research methods include a combination of quantitative and qualitative research methods, such as analysis, synthesis, statistical data processing, focus group and expert questionnaire and other methods. The survey is focused sectors Construction and Real Estate Operations - primary on managers and employees of enterprises who are working in development of building projects, construction of residential and nonresidential buildings, real estate agencies, management of real estate on a fee or contract basis, renting and operating of own or leased real estate, buying and selling of own real estate. Methodological steps of index calculation was approbated in the study by Kauškale and Geipele (2017). Additive aggregation and pair comparison methods are used for data aggregation (Gan et al., 2017). For instance, the framework for evaluating sustainability indicators in the real estate industry (Rogmans, Ghunaim, 2016) was more

${ }^{1}$ Institute of Civil Engineering and Real Estate Economics, Faculty of Engineering Economics and Management, Riga Technical University. Latvia

2Professor of the Faculty of Engineering Economics and Management, Director of the Institute of Civil Engineering and Real Estate Economics, the Head of the Department of the Civil Construction and Real Estate Economics and Management at Riga Technical University, Latvia. 
focused on unit evaluation. Theoretical overview includes world and European experience on the research question and the related problems. The research includes integrated approach of assessment of the real estate market.

\section{Theoretical Overview of Problematic Issues of Sustainable Development of the Real Estate Market}

The current important aspect of the national strategic development plans around the world is the development of sustainable investment environment (Vanags, Butane, 2013). For example, the main focus of the sustainable development strategy in Lithuania was on "eco-effectiveness indicator", including energy and other natural resource consumption per GDP unit, emissions of pollutants per GDP unit and other criteria (Lepkova, 2010, as cited in Kauškale, Geipele, 2016c).

As part of ESG criteria (economic, social and governance) (European Political Strategy Centre, 2017), the governmental factors have been analysed separately for financial evaluation and are of great importance especially for investment analysis (Binovska, Kauškale, Vanags, 2018). Governmental factors are considered political and legal factors in the analysis. The summary of problematic factors affecting the sustainable development of the real estate market, including the international experience grouped by economic, social and environmental dimensions globally are shown in Table 1.

Table 1. Problems and Difficulties of Sustainable Development of the Real Estate Market International Experience (Source: developed by the authors on the basis of Kauškale et al., 2017; Kauškale, Geipele 2016a, 2016b, 2016c; Geipele et al., 2014)

\begin{tabular}{|c|c|c|}
\hline Factor & Statement & Main problem \\
\hline Economic & $\begin{array}{l}\text { - "Pei Kuang (Kuang, 2014) in a model found an } \\
\text { important interconnection, which not always was } \\
\text { covered by the real estate analysis, that in a } \\
\text { collateral-constrained economy house prices } \\
\text { depend on quantities on the leverage ratio". } \\
\text { - "Real estate imbalances influence on bank } \\
\text { stability is comparable with the impact of } \\
\text { nonperforming credit shares, cost efficiency and } \\
\text { liquidity levels, and universal banks have more } \\
\text { advantages than the specialized banks for } \\
\text { portfolio diversification" (Koetter, Poghosyan } \\
\text { 2010). } \\
\text { - According to the research by Eddie C. M. Hui } \\
\text { and Ka Kwan Kevin Chan (2014), "correlation of } \\
\text { a type of asset market between two countries } \\
\text { usually increases during a financial crisis, i.e., they } \\
\text { either move up together or, more commonly, } \\
\text { move down together, and even correlation } \\
\text { between different types of asset markets may } \\
\text { increase too". }\end{array}$ & $\begin{array}{l}\text { "During a financial crisis, } \\
\text { correlation of a type of } \\
\text { asset market between two } \\
\text { countries usually } \\
\text { increases, i.e., they either } \\
\text { move up together or, } \\
\text { more commonly, move } \\
\text { down together" }\end{array}$ \\
\hline
\end{tabular}




\begin{tabular}{|c|c|c|}
\hline & $\begin{array}{l}\text { - "Real estate needs effective management in } \\
\text { order to generate income in a greater degree than } \\
\text { other assets" (Asaul, 2004). } \\
\text { - "Large price jumps exist in the international } \\
\text { securitized real estate markets in the crisis and } \\
\text { non-crisis periods" (Li J., Li G., Zhou Y., 2015). } \\
\text { - "Simon Kuznets in his work "Economic } \\
\text { Growth and Income Inequality" (1955) believed } \\
\text { that economic growth in poor countries increased } \\
\text { the income gap between rich and poor people". } \\
\text { - "Real estate is inseparable from human } \\
\text { economy in its social form, and all plans of social } \\
\text { reform should be better directed toward an } \\
\text { appropriate distribution of economic goods" } \\
\text { (Menger, 1871). } \\
\text { cannot be a point of reference for forecast in all } \\
\text { situations" (Hui, Wang, 2015). } \\
\text { does not always repeat the previous cycle and it } \\
\text { poom growth, and for the forecasting of cycles it } \\
\text { - "Jignificant indicator for the forecasting of the } \\
\text { - "John Kenneth Galbraith (1958) was convinced } \\
\text { that the economic imbalances were resulting also } \\
\text { from the consumer society, because too many } \\
\text { resources were driven to production of goods but } \\
\text { the inadequate resources were driven to the } \\
\text { public needs and infrastructure". } \\
\text { - "The individual personality preferences affect } \\
\text { the real estate market equilibrium and outperform } \\
\text { - 2014). }\end{array}$ & 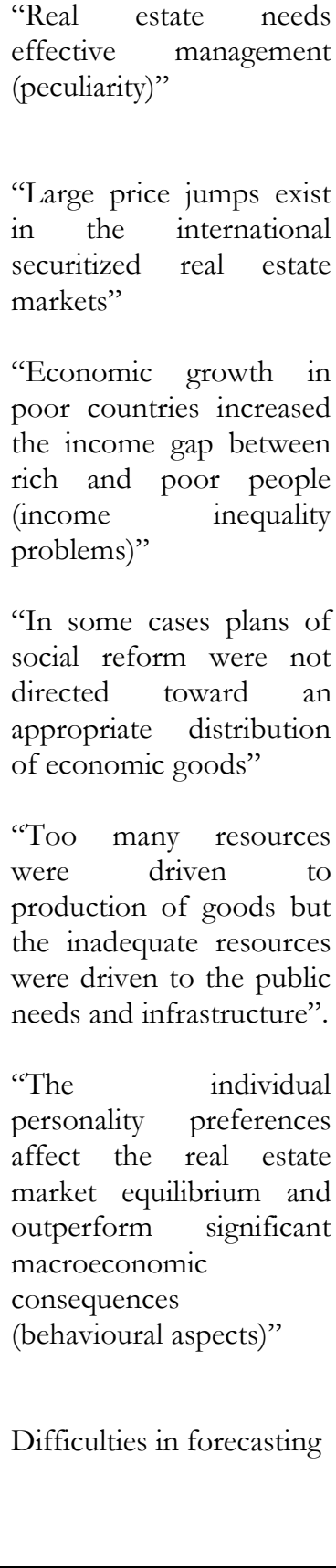 \\
\hline Social & $\begin{array}{l}\text { - "Population growth and economic development } \\
\text { are marked as ubiquitous drivers of } \\
\text { environmental change with a special attention to } \\
\text { energy, transport, urbanization and globalization" } \\
\text { (UNEP, 2012). }\end{array}$ & $\begin{array}{l}\text { "Population growth and } \\
\text { economic development } \\
\text { are marked as ubiquitous } \\
\text { drivers of environmental } \\
\text { change } \quad \text { (negative }\end{array}$ \\
\hline
\end{tabular}




\begin{tabular}{|c|c|c|}
\hline & $\begin{array}{l}\text { - "Demographic trends are part of urban } \\
\text { dynamics, and can affect residential area as large } \\
\text { housing estate" (Hatemi-J, Roca, Al-Shayeb, } \\
\text { 2014, p. 123.). } \\
\text { - "It is expected that in } 2050 \text { over a quarter of the } \\
\text { population will be aged over } 65 \text { years, compared } \\
\text { to about } 15 \% \text { nowadays" (Manders et al., 2012). } \\
\text { - "As the ageing of population is observed in } \\
\text { some regions in the world, the necessity and } \\
\text { importance of age-friendly building construction } \\
\text { will also grow" (Ŝtaube et al., 2016). }\end{array}$ & $\begin{array}{l}\text { tendencies)" } \\
\text { "Demographic tendencies } \\
\text { can lead to difficulties in } \\
\text { construction industry, } \\
\text { social problems" } \\
\text { Ageing of population }\end{array}$ \\
\hline Environmental & $\begin{array}{l}\text { - "Construction and demolition waste has } \\
\text { become a critical issue as the volume of } \\
\text { construction activity was undertaken globally, } \\
\text { therefore the construction waste disposal } \\
\text { charging schemes have been marked in } \\
\text { economies as the most effective ways of } \\
\text { managing construction waste" (Lu, Peng, } \\
\text { Webster, Zuo, 2015). } \\
\text { - "Agricultural land is projected to expand } \\
\text { globally at diminishing rate" (Manders et al., } \\
\text { 2012). } \\
\text { " "Interconnection between pollution and the } \\
\text { level of income is important as well. The } \\
\text { Environmental Kuznets' Curve (EKC) } \\
\text { hypothesis" (Kuznets, 1955). } \\
\text { - "The complexity of increase of green building } \\
\text { construction for all market participants arises } \\
\text { from the fact that sometimes environmental, } \\
\text { economic and social aspects are also } \\
\text { contradictory" (Guo, Ma, 2008). } \\
\text { - "In energy policy implementation, special } \\
\text { attention should be paid to a range of planning } \\
\text { and managing problems of energy efficiency, } \\
\text { energy issue should be solved also at district level } \\
\text { (Actinsa, Geipele, Zeltinsš, 2015) and special } \\
\text { attention should be paid to energy efficiency } \\
\text { process management" (Actina, 2015). }\end{array}$ & $\begin{array}{l}\text { "Construction } \\
\text { demolition waste has } \\
\text { become a critical issue } \\
\text { because of the volume of } \\
\text { construction activity } \\
\text { being undertaken } \\
\text { globally" } \\
\text { "Reduction in agricultural } \\
\text { land (while } \\
\text { predictions gansion } \\
\text { growing of population)"* } \\
\text { "Interconnection } \\
\text { between pollution and } \\
\text { the level of income (risk)" } \\
\text { "Environmental, } \\
\text { economic and social } \\
\text { aspects may } \\
\text { contradictory" be } \\
\text { "Range of planning and } \\
\text { managing problems of } \\
\text { energy efficiency" }\end{array}$ \\
\hline
\end{tabular}


On the basis of the model of contractionary and motivating factors of sustainable development of the real estate market and construction industry (Kauškale et al., 2018), the authors offers the model of motivating and contractionary factors affecting sustainable development of the real estate market by levels, which is shown in Table 2.

Table 2. The Model of Motivating and Contractionary Factors Affecting Sustainable Development of the Real Estate Market by Levels (Source: developed by the authors)

\begin{tabular}{|c|c|c|}
\hline Level & Motivating factors & Contractionary factors \\
\hline 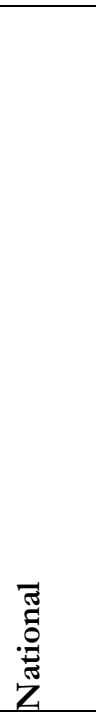 & $\begin{array}{l}\text { Increase in economic activity } \\
\text { Changes in development of promoting } \\
\text { laws } \\
\text { Globalization } \\
\text { Changes in demography - rapid growth } \\
\text { of people living in urban areas } \\
\text { Policy support - importance of funding } \\
\text { and government support } \\
\text { Pressure to innovate - open } \\
\text { innovation, increased competition, } \\
\text { innovation spiral and other } \\
\text { Tax policy } \\
\text { Increase in housing affordability } \\
\text { International opportunities }\end{array}$ & $\begin{array}{l}\text { Inflation risk } \\
\text { Interest rate risk } \\
\text { Legislative risk } \\
\text { Environmental risk } \\
\text { Lack of consistent and long-term policy } \\
\text { frameworks (national and sub-national), } \\
\text { including regulations and incentive schemes } \\
\text { Ineffective national tax system } \\
\text { Government decisions are not focused on } \\
\text { the development } \\
\text { Absence of the real long-term economic } \\
\text { development plan } \\
\text { Monetary policy is oriented to the exchange } \\
\text { rate rather than to price stability } \\
\text { Economic cycles (recession, crisis) } \\
\text { High tax burden, tax rates, policy instability } \\
\text { Threat of the loss of foreign market and } \\
\text { currency fluctuations }\end{array}$ \\
\hline$\underset{\Xi}{己}$ & $\begin{array}{l}\text { High operating yield, average } \\
\text { profitability of the industry (economic } \\
\text { factor), financial opportunities of the } \\
\text { enterprise. } \\
\text { Increase in economic activity, economic } \\
\text { factors characterising economic } \\
\text { recovery, increase in the number of } \\
\text { buyers, increase in investment volume, } \\
\text { etc. } \\
\text { Infrastructure, demographic factors, } \\
\text { increase in demand } \\
\text { Emergence of new technologies }\end{array}$ & $\begin{array}{l}\text { Slowdown in market rise, Lack of adequate } \\
\text { financing models; } \\
\text { High level of competition in a sector or } \\
\text { insufficient competition (lack of } \\
\text { competition), which does not stimulate the } \\
\text { development of industry, incompetence of } \\
\text { employees, advertising restrictions, industry } \\
\text { development risks - monopoly for any } \\
\text { market participant; } \\
\text { Small market, too closed or too open } \\
\text { market; } \\
\text { Lack of local raw materials - for } \\
\text { construction industry; Greater exposure to } \\
\text { raw material price fluctuations; } \\
\text { Dependence on the changes in the global } \\
\text { economy; Decrease in demand } / \\
\text { purchasing capacity, real estate cycles. }\end{array}$ \\
\hline  & $\begin{array}{l}\text { Financial consideration, enterprise } \\
\text { reputation, benefits for employees - } \\
\text { higher salary opportunities, good } \\
\text { working conditions, growth } \\
\text { opportunities, interesting work, etc., } \\
\text { implementation of motivating theories }\end{array}$ & $\begin{array}{l}\text { Selective risk; } \\
\text { Increase in the impact of the buyers and } \\
\text { suppliers; } \\
\text { Business risk; } \\
\text { Financial risk (liquidity risk, management } \\
\text { risk) }\end{array}$ \\
\hline
\end{tabular}




\begin{tabular}{|c|c|}
\hline $\begin{array}{l}\text { (Herzberg and other motivation } \\
\text { theories), internal drivers, strategic } \\
\text { management priority, employee } \\
\text { involvement, costing, health and safety, } \\
\text { marketing issues, profit opportunities, } \\
\text { external driver, legislation and } \\
\text { regulations, market pressure, public } \\
\text { pressure. } \\
\text { Globalization for owners of the } \\
\text { enterprises: organisation maintenance, } \\
\text { capital raising, dividends, high salaries, } \\
\text { development of the company. } \\
\text { Developers: opportunities for selling } \\
\text { real estate units to the local and foreign } \\
\text { clients, brand awareness, increase in } \\
\text { market share, by reducing the market } \\
\text { share of other competitors, revenues } \\
\text { from real estate rent. } \\
\text { Banks: There is interest in an increase } \\
\text { in the number of customers; obtaining } \\
\text { the credit amount (from real estate } \\
\text { sellers who sold the real estate to } \\
\text { foreign customers and paid back credits } \\
\text { to the bank \%). } \\
\text { Providers of marketing external } \\
\text { services: revenues from ads, etc. } \\
\text { Development of different types of } \\
\text { marketing communications } \\
\text { Local community, real estate market } \\
\text { development (minus - housing } \\
\text { availability). Opportunities for selling } \\
\text { real estate. Money is partially remaining } \\
\text { in the country, which is contributing to } \\
\text { the national development. } \\
\text { National, state organisations. Largest } \\
\text { taxpayers. Taxes increase expenses for } \\
\text { the acquisition of real estate. }\end{array}$ & $\begin{array}{l}\text { Lack of awareness and leadership } \\
\text { particularly related to challenges in making } \\
\text { the business case; } \\
\text { Workforce capacity and the need for proper } \\
\text { skills and collaboration along the value } \\
\text { chain to implement the right solutions; } \\
\text { Difficult start; } \\
\text { Limited capital and competition for } \\
\text { resources; } \\
\text { Shortage of actionable information tailored } \\
\text { to grocery stores; } \\
\text { Failure to consider all benefits over project } \\
\text { life; } \\
\text { Lack of specific integrated design methods } \\
\text { adapted to grocery store retrofits; } \\
\text { Need for reliable data to support business } \\
\text { case; } \\
\text { Incorrect assessment of demand - low } \\
\text { production volume and too high costs; } \\
\text { Insufficient production capacity and } \\
\text { efficiency compared to foreign competitors; } \\
\text { Absence of the enterprise strategy; } \\
\text { Price adjustment efforts in the EU; } \\
\text { Variable overall price level, selective risk; } \\
\text { Inadequately educated workforce (legal } \\
\text { complexities); } \\
\text { Acquisition risks, entitlement risks, site } \\
\text { risks; } \\
\text { Market full lease-up risks; } \\
\text { Operating risks, sale risks, timing risks; } \\
\text { Growth of influence power of buyers and } \\
\text { suppliers. }\end{array}$ \\
\hline
\end{tabular}

Note: Factors are developed based on Peterson, Gammill, 2010; WBCSD Publication Library, Energy Efficiency in Buildings 2.0 (n.d.); WBCSD Publication Library, Energy Efficiency in Buildings. Action Plan (2015); Baccarne, Mechant, Schuurman (2014); Hines, 2001; Peiser, Frei, 2005; Lapigin, Y.N., Lapigin D., 2009; Wofford, Clauretie, 1992.

Taking into account the fact that the investments in the real estate market and construction industry are of great importance, they are also affecting national economy development (Kauškale, Geipele, 2015b).

Since 2005, based on Klaus Schwab's idea of 1979, the World Economic Forum has been publishing the Global Competitiveness Index (GCI) developed by Xavier Sala-iMartín in collaboration with the World Economic Forum (World Economic Forum, The Global Competitiveness Report Schwab, 2016) - basic requirements subindex, efficiency 
enhancers subindex and innovation and sophistication factors subindex. Competitiveness is defined as "the set of institutions, policies and factors that determine the level of productivity of the economy, which in turn sets the level of prosperity that the country can achieve" (World Economic Forum, The Global Competitiveness Report Schwab, 2016). According to the Global Competitiveness Index 2016-2017 Rankings, the top 10 countries with the highest sustainability rating are shown in Table 3.

Table 3. The Global Competitiveness Index 2016-2017 Rankings (2016) and Doing Business Rankings: World Bank, 2017 (compiled by the authors)

\begin{tabular}{|c|c|c|c|c|c|c|c|c|}
\hline $\begin{array}{l}\text { No } \\
\text {. }\end{array}$ & $\begin{array}{l}\text { Country } \\
\text { (a) }\end{array}$ & $\begin{array}{l}\text { Scor } \\
\mathrm{e}\end{array}$ & $\begin{array}{l}\text { DB } \\
\text { dealing } \\
\text { with } \\
\text { constructi } \\
\text { on permit } \\
\text { (for } \\
\text { countries } \\
\text { a) }\end{array}$ & $\begin{array}{l}\text { Registeri } \\
\text { ng } \\
\text { property }\end{array}$ & $\begin{array}{l}\text { Score } \\
\text { in Ease } \\
\text { of } \\
\text { Doing } \\
\text { Busine } \\
\text { ss }\end{array}$ & $\begin{array}{l}\text { Country } \\
\text { rank (b) }\end{array}$ & $\begin{array}{l}\text { Dealing } \\
\text { with } \\
\text { constructi } \\
\text { on permit } \\
\text { (for } \\
\text { countries } \\
\text { b) }\end{array}$ & $\begin{array}{l}\text { Registeri } \\
\text { ng } \\
\text { property }\end{array}$ \\
\hline 1. & $\begin{array}{l}\text { Switzerlan } \\
\text { d }\end{array}$ & 5.81 & 62 & 16 & 33 & $\begin{array}{l}\text { New } \\
\text { Zealand }\end{array}$ & 3 & 1 \\
\hline 2. & Singapore & 5.72 & 16 & 19 & 2 & $\begin{array}{l}\text { Singapo } \\
\text { re }\end{array}$ & 16 & 19 \\
\hline 3. & $\begin{array}{l}\text { United } \\
\text { States }\end{array}$ & 5.70 & 36 & 37 & 6 & $\begin{array}{l}\text { Denmar } \\
\mathrm{k}\end{array}$ & 1 & 11 \\
\hline 4. & $\begin{array}{l}\text { Netherlan } \\
\text { ds }\end{array}$ & 5.57 & 32 & 76 & 30 & $\begin{array}{l}\text { Korea, } \\
\text { Rep. }\end{array}$ & 28 & 39 \\
\hline 5. & Germany & 5.57 & 20 & 10 & 28 & $\begin{array}{l}\text { Hong } \\
\text { Kong, } \\
\text { SAR } \\
\text { China }\end{array}$ & 5 & 55 \\
\hline 6. & Sweden & 5.53 & 27 & 9 & 10 & $\begin{array}{l}\text { United } \\
\text { States }\end{array}$ & 36 & 37 \\
\hline 7. & $\begin{array}{l}\text { United } \\
\text { Kingdom }\end{array}$ & 5.49 & 14 & 47 & 7 & $\begin{array}{l}\text { United } \\
\text { Kingdo } \\
\mathrm{m}\end{array}$ & 14 & 47 \\
\hline 8. & Japan & 5.48 & 50 & 52 & 34 & Norway & 21 & 14 \\
\hline 9. & $\begin{array}{l}\text { Hong } \\
\text { Kong } \\
\text { SAR }\end{array}$ & 5.48 & 5 & 55 & 5 & Georgia & 29 & 4 \\
\hline 10. & Finland & 5.44 & 16 & 11 & 13 & Sweden & 27 & 9 \\
\hline 49. & Latvia & 4.45 & 49 & 22 & 19 & $\begin{array}{l}\text { Rank } \\
\text { (19) }\end{array}$ & 20 & 9 \\
\hline 30 & Estonia & 4.78 & 8 & 6 & 12 & $\begin{array}{l}\text { Rank } \\
\text { (12) }\end{array}$ & 5 & 2 \\
\hline $\begin{array}{l}\text { n.d } \\
.\end{array}$ & $\begin{array}{l}\text { Lithuani } \\
\text { a }\end{array}$ & n.d. & 12 & 3 & 16 & $\begin{array}{l}\text { Rank } \\
\text { (16) }\end{array}$ & 2 & 1 \\
\hline
\end{tabular}


n.d. - no data

a) according to the Global Competitiveness index. Note: The Global Competitiveness Index captures the determinants of long-term growth. Recent developments (such as Brexit, commodity price changes and market volatility) are reflected only in-so-far as they have an impact on data measuring these determinants. The Index should be interpreted in this context. Scale ranges from 1 to 7, 2015-2016 rank out of 140 economies; 20162017 rank - according to the 138 economies (according to the Global Competitiveness Report, 2016, p. 232).

b) according to Ease of Doing Business (World Bank)

The results of Global Competitiveness Index 2016-2017 and the analysis of the most problematic factors of doing business in construction and real estate areas help identify the factors that affect sustainable development of the real estate market; the comparison of situation in the Baltic States provides a comparative analysis showing the areas where improvements can be carried out.

\section{Methodology}

The assessment of sustainable development of the real estate market should have a complex multilevel approach with particular adaptation to the real estate market of Latvia. The entrepreneurial environment is constantly changing, so the decisions made should be analysed not only in terms of the business cycle and real estate cycle, but also from the perspective of the influencing PESTEL factors. The PESTEL dimensions and subcriteria affecting sustainable development of the real estate market are described and analysed in this Subchapter of the Thesis. The authors have developed and summarised the PESTEL criteria affecting sustainable development of the real estate market, as each of these factors influences sustainable development in general and sustainable development of the real estate market in particular. The model of assessment of factors of sustainable development of the real estate market is shown in Fig. 1.1. 


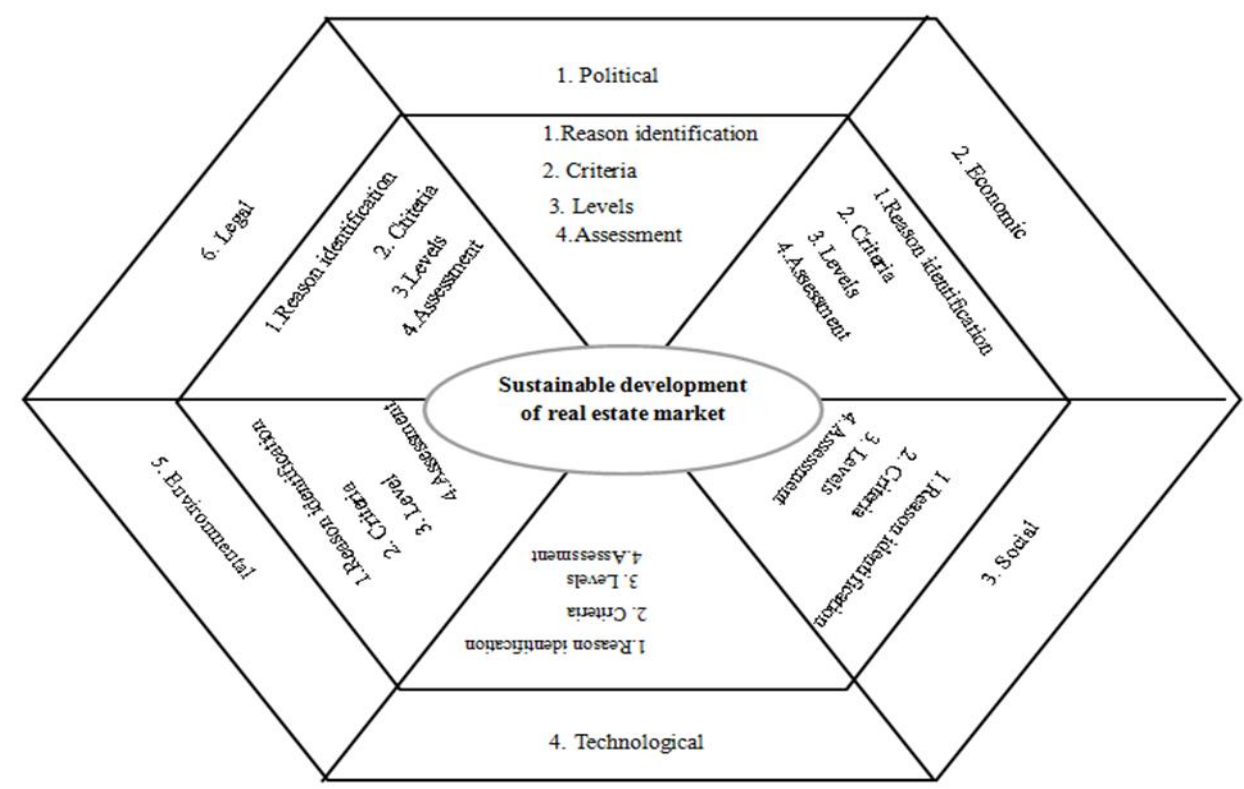

Figure 1. The schematic model of the assessment of factors of sustainable development of the real estate market

(Source: developed by the authors)

After argumentation of the necessity of evaluation of each factor that has been identified through complex analysis of literature and in two focus groups (Kauškale et al., 2017), the criteria for each group have been identified. The PESTEL dimensions and subcriteria affecting sustainable development of the real estate market are shown in Table 4.

Table 4. PESTEL Dimensions and Criteria Affecting the Real Estate Market (Kauškale, Geipele, 2017)

\begin{tabular}{|l|l|}
\hline Factor(s) & Criteria \\
\hline Political & $\begin{array}{l}\text { Political stability, real estate industry regulation, internal political problems, } \\
\text { international relationships, level of corruption }\end{array}$ \\
\hline Economic & $\begin{array}{l}\text { GDP in volume, \% change, GDP per capita, private final consumption in } \\
\text { volume, } \%, \text { investments in volume, \%, international trade balance, mln euro, } \\
\text { current account - total, mln euro, inflation, \%, unemployment, by age groups, } \\
\text { by industry, by gender etc., \%, labour cost index, \%, employment, \%, industrial } \\
\text { producer prices, \%, industrial production, \%, construction production, \%, } \\
\text { inflation, government finance - government deficit/surplus, \%, general } \\
\text { government gross debt, \%, economic sentiment indicator, index, 3 months } \\
\text { interest rate, \%, long-term government bond yields, \%, euro-dollar exchange } \\
\text { rate, } \$, \text { number of enhanced mortgages, investments in construction, real estate } \\
\text { investments, deposit rates, level of profit inside industry, number of registered } \\
\text { real estate purchase agreements, mortgage interest rates, purchasing power } \\
\text { parities, average salaries, wage level within the branch, material prices, labour } \\
\text { costs, price of resources, real estate price level, house price index, real estate } \\
\text { rent prices, number of registered rents, real estate taxes, tax burden, real estate }\end{array}$ \\
\hline
\end{tabular}




\begin{tabular}{|l|l|}
\hline Social & $\begin{array}{l}\text { vacancy rates for various types of real estate, new construction volumes, new } \\
\text { issued building permits etc. }\end{array}$ \\
\hline $\begin{array}{l}\text { The demographic situation in the country - number of inhabitants, population } \\
\text { density, net migration, birth balance, average family/households size, age level, } \\
\text { income by age and gender, level of education, structure of employment, } \\
\text { national culture and traditions, unemployment rate in the country, employee } \\
\text { turnover of the sector, housing affordability, Gini coefficient, S80/S80 quintiles, } \\
\text { population density, which is particularly important in central business districts } \\
\text { and high-rise residential neighbourhoods, educational characteristics, skill levels, } \\
\text { and employment categories, which are particularly important in industrial or } \\
\text { high-technology districts, age levels, which are particularly important in } \\
\text { residential neighbourhoods, household size employment levels and types of } \\
\text { employment (temporary, seasonal, or chronic), extent of crime. }\end{array}$ \\
\hline $\begin{array}{l}\text { Construction technology and equipment development, new construction } \\
\text { materials and resources in the market, customer relationship management } \\
\text { computer technology development, etc. }\end{array}$ \\
\hline Legal & $\begin{array}{l}\text { Citizens' ability and desire to buy eco-home or demand for eco-homes (green } \\
\text { buildings), sustainability of construction of units, impact of construction of } \\
\text { units on the environment, number of buildings with green building certification, } \\
\text { COn emissions, environmental taxes in general and by economic activity, } \\
\text { resource productivity, energy efficiency, environmental protection expenditures, } \\
\text { health and wellbeing, indoor environmental quality, land use, innovation, } \\
\text { materials, resources, energy affordability, pollution, renewable technologies, } \\
\text { transport, ecology waste, water, green building certification indicators, climate } \\
\text { change and other indicators in the construction industry and overall in the } \\
\text { country. }\end{array}$ \\
$\begin{array}{l}\text { Valid legislation and decision-making speed, international law, European } \\
\text { directives, changes in the construction and real estate business market related } \\
\text { laws, legal aspects of zoning and land use, legal aspects of construction, } \\
\text { entrepreneurship, environmental regulations, special assessments and other } \\
\text { factors. }\end{array}$ \\
\hline thendal
\end{tabular}

The matrix of the factors affecting development of the real estate market (REMDIF) is shown in Equation 1.

\begin{tabular}{|c|c|c|c|c|c|c|}
\hline \multirow{6}{*}{ REMDIF $=$} & $P_{11}$ & $P_{12}$ & $P_{13}$ & $\ldots P_{1 i}$ & $\ldots$ & $P_{1 n}$ \\
\hline & & $E_{22}$ & $E_{23}$ & $\ldots E_{2 i}$ & $\ldots$ & $E_{2 n}$ \\
\hline & $S_{31}$ & $S_{32}$ & $S_{33}$ & $\ldots S_{3 i}$ & $\ldots$ & $S_{3 n}$ \\
\hline & $T_{41}$ & $T_{42}$ & $T_{43}$ & $\ldots T_{4 i}$ & $\ldots$ & $T_{4 n}$ \\
\hline & $E_{51}$ & $E_{52}$ & $E_{53}$ & $\ldots E_{5 i}$ & & $E_{5 n}$ \\
\hline & $L_{61}$ & $L_{62}$ & $L_{63}$ & $\ldots L_{6 i}$ & $\cdots$ & \\
\hline
\end{tabular}

Methodological steps of index calculation was approbated in the study by Kauškale and Geipele (2017). PESTEL factors also affect economy, real estate market and decisionmaking of investments of construction at the same time, but it is necessary to take into account that each country has its own characteristics and availability of information. Pair analysis and expert evaluation methods are used for factor weighting that previously were 
analysed and developed in the territory development index calculations and REF. Weighted arithmetic mean can be used for sensitivity analysis and quantification of uncertainty in sustainability assessment (Pollesch, Dale, 2015). Additive methods should not be used in case of interaction among indicators. The IBM SPSS Statistics version 25.0.0 and Excel are used for statistical data analysis. The proposed methodological solution is more focused not on sustainability criteria of the real estate unit, but on the assessment of the overall development of the real estate market. The factors affecting sustainable development of the real estate market should also be analysed at multiple levels, at least at the industry and national levels.

Methodology of the survey: research, using the qualitative and quantitative approach. Data collection has been performed using PAPI (Paper and Pencil Interviews) and focus group interview. The respondents are the representatives of the real estate agencies, managers of real estate on a fee or contract basis, managers of the building projects, construction of residential and non-residential buildings, civil engineering, renting and operating of own or leased real estate, buying and selling their own real estate. Structure of respondents has been developed according to NACE 2.rev. classification (European Commission, 2006) and includes the described groups of respondents. Having performed a complex scientific and practical analysis, a focus group interview has been developed and the feedbacks of the experts received. The direct interview method has been used. Focus group method has been chosen for the acquisition of research results, and the focus has been put on bighly professional and educated experts in the question under research. "Nominal groups" are groups of participants, who do not interact and may not even meet (Marczak, Sewell, n.d.). Nominal group technique has also been applied by Brauers, Lepkova (2003). Nominal group technique - a group of especially knowledgeable experts. Nominal group technique: a format for focus groups (Sumsion, 2002).

The data collection has been performed using the survey method - expert evaluation, and approbation has been implemented within focus group meeting. The focus group has been moderated by the author of the research. Focus groups have been originally called "focused interviews" or "group depth interviews" (Linton, 2005). Focus groups can be homogeneous or heterogeneous, and the group participants should have depth knowledge of the topic under discussion. Length varies from 1 to 2 hours; the number of participants is 6-12. There should also be a skilled moderator. Open-ended (to generate qualitative data) or closed-ended (to generate quantitative data) questions can be included. It is necessary to draw up a report of findings. "Data analysis could include:

- bullet list of information learned;

- comparative analysis of two solutions;

- summary of responses collected for each question;

- focus group or brainstorming workshop, which involves eight to ten" (Erzah, 2011).

Focus group is a widely used practice also nowadays (Carey, 2015; Baxter et al., 2015). As cited in the study by Kauškale et al. (2018), "the main purpose of focus group research is to draw upon respondents' attitudes, feelings, beliefs, experiences and reactions in a way in which would not be feasible using other methods, for example, observation, one-toone interviewing, or questionnaire surveys, and focus groups can help to explore or generate hypotheses (Powell, Single, 1996) and develop questions or concepts for questionnaires and interview guides (Hoppe et al., 1995; Lankshear, 1993). A.H. Van de Ven and A.L. Delbecq (1972) as well as Gallagher et al. (1993) stated that the selected 
individuals should have experience, expertise and perception that relate to the problem being explored. They suggested that there should be eight members per group and that several sessions should be conducted for different groups.

The questionnaire is of qualitative and quantitative character, as a structure of question is mixed and methods are integrated. Triangulation methods have been used in the research. The answers to the questionnaires included three variants - ranking responses, evaluative and alternate responses. In the survey, open-ended and close-ended questions have been used, as well as discussions have taken place and conclusions have been drawn. The research has demonstrated that there are problems in sustainable development of the real estate market by assessing the affecting factors and identifying the possible areas of improvement. Maxwell qualitative research design (Maxwell, 2005) has been used to develop the questionnaire. The conducted research includes goals, methods, conceptual framework and validity, which are integrated in the research methodology. Maxwell qualitative research design is shown in Figure 2.



Figure 2. Interactive model of the research design (Maxwell, 2010, p. 217)

The expert interview as a method of data production has already played a significant role anyway, and the empirical social research as a frequently used instrument for data collection resulted from the expert interviews. In expert interview, there can be qualitative and quantitative orientations. In this sense, exploratory interviews help thematically to structure the research area and to generate hypotheses. The knowledgeoriented focus of the experts is also recommendable and dedicated to moderation technology, non-interventionist moderation ideal and methodological orientation to research process (Mayring, 2010). Data processing included validation, sorting, summarisation, aggregation, analysis, reporting. Focus group discussions included:

- development of guidelines for organisation of focus group;

- management of focus group;

- analysis of results.

The questions of survey included quantitative and qualitative aspects.

Sampling: The survey focuses on the managers and employees of the enterprises who are operating in the economic sector "Real Estate Operations" (L68) and "Construction" (F41), such as managers and employees of real estate agencies, managers of the real estate sector on a fee or contract basis, managers of the building projects, construction of residential and non-residential buildings, civil engineering, renting and operating of 
own or leased real estate, buying and selling of own real estate and delegated from real estate, construction, finance, environmental and academic sectors (interdisciplinary).

Included areas of experience

L68 - Real estate activities

-L68.1 - Buying and selling of own real estate

-L68.2 - Renting and operating of own or leased real estate

L68.3 - Real estate activities on a fee or contract basis

-L68.3.1 - Real estate agencies

-L68.3.2 - Management of real estate on a fee or contract basis.

The survey in particular also included the following areas: Construction of Buildings

(F41), Construction of Residential and Non-residential Buildings (41.1) and Development of Construction Projects (41.2), Financial and Insurance Activities, as these activities are important for the sustainable development of real estate market.

\section{Assessment of Sustainable Development of the Real Estate Market: Case of Latvia}

For the assessment of sustainable development of the real estate market in Latvia, a qualitative research technique has been implemented and a survey has been developed. According to the Public Process Research Centre (2012), the qualitative research also provides deeper insight into the problems of society, understanding of the attitudes and actions motivation, being closer to the respondent (more qualitative responses), and a possibility to change research parameters in the course of research. Qualitative research methods used in the present research include expert questionnaires, focus group and observation methods.

According to the University of Leicester (University of Surrey, n.d.), "qualitative research data collection methods are time consuming; therefore, data is usually collected from a smaller sample; therefore, the qualitative research requires more resources, and data collection approaches for qualitative research involved both (which has also been done during the research process):

1. the direct interaction with individuals on a one-to-one basis;

2. and the direct interaction with individuals in a group setting".

The aim of the survey - to identify the main problems of the real estate market, the factors affecting its development and other issues related to sustainable development of the real estate market.

The survey focuses on the real estate market experts who are operating in the economic sector of transactions in the real estate market, and on the experts in the field of science, whose research and scope of activities are associated with real estate for more than 10 years, $28 \%$ of experts are representatives of the academic area as well. Information about the survey is provided in Table 5.

Table 5. Information about the Focus Group and the Survey (developed by the authors)

\begin{tabular}{|l|l|}
\hline Criterion & Ratio \\
\hline Type & Focus group discussion and expert interviews \\
\hline Date & $\begin{array}{l}\text { 30 June 2016 } \\
\text { 11 August 2016 }\end{array}$ \\
\hline
\end{tabular}




\begin{tabular}{|l|l|}
\hline Period of questionnaire & 2016 M6, M7, M8 \\
\hline Description of experts and & $\begin{array}{l}\text { The survey focuses on the real estate market experts who are } \\
\text { operating in the economic sector "Real Estate Operations" and } \\
\text { "Construction", and on the experts in the field of science, whose } \\
\text { research and scope of activities are associated with real estate - a } \\
\text { group of especially knowledgeable experts representing real estate, } \\
\text { construction, finance, environmental and academic sectors } \\
\text { (interdisciplinary) }\end{array}$ \\
\hline Focus group & 19 experts \\
\hline Survey unit & Experts \\
\hline $\begin{array}{l}\text { Professional experience of } \\
\text { experts }\end{array}$ & 10 years and more \\
\hline $\begin{array}{l}\text { Number of respondents - } \\
\text { participants of the survey } \\
\text { (nominal group) }\end{array}$ & 17 \\
\hline
\end{tabular}

Structure of the respondents - area and education, some experts' work in more than one area. Structure of the respondents and their education are shown in Figs. $3 \mathrm{a}$ and $3 \mathrm{~b}$.

a)

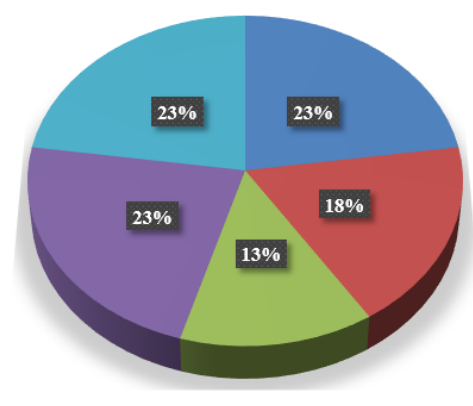

Figure $3 a$. Structure of the respondents

Figure 3b. Education of the respondents

(Source: own work based on the survey) b)


- Doctoral degree

Master`s degree

Bachelor's degree

Three main problems are ranked by relevance order, evaluated by the frequency of the answers of the respondents. The full range of problems has been identified previously in Kauškale, Geipele (2016b).

Table 6. Three Main Problems of Sustainable Development of the National Economy, Real Estate Market and Construction Industry, Mentioned by the Experts (Source: own work based on the survey)

\begin{tabular}{|l|l|l|}
\hline $\begin{array}{l}\text { Problematic areas of the } \\
\text { development of the } \\
\text { national economy }\end{array}$ & $\begin{array}{l}\text { Problematic areas of the } \\
\text { development of the real estate } \\
\text { market }\end{array}$ & $\begin{array}{l}\text { Problematic areas of the } \\
\text { development of the } \\
\text { construction industry }\end{array}$ \\
\hline
\end{tabular}




\begin{tabular}{|c|c|c|}
\hline $\begin{array}{l}\text { - Tax system and } \\
\text { social system. Necessity for } \\
\text { equal income distribution } \\
\text { and for effective use of } \\
\text { resources } \\
\text { - Regional policy } \\
\text { improvements } \\
\text { - Impact of international } \\
\text { factors }\end{array}$ & $\begin{array}{l}\text { - Cyclical development } \\
\text { nature of the real estate market - } \\
\text { imbalance. Necessity to achieve } \\
\text { sustainable development } \\
\text { - Sensitivity of the real } \\
\text { estate market and its participants to } \\
\text { external factors and economic } \\
\text { development } \\
\text { - Real estate market } \\
\text { overheat }\end{array}$ & $\begin{array}{l}\text { - Significant impact of } \\
\text { external factors - impact } \\
\text { of the economic } \\
\text { development and real } \\
\text { estate market } \\
\text { - Investment returns } \\
\text { - Availability of financing }\end{array}$ \\
\hline
\end{tabular}

The motivating and contractionary factors for sustainable development of the real estate market by levels have been identified. Three main factors selected by the experts are shown in Table 7 . The full range of factors is provided in Table 2.

Table 7. Three Main Motivating and Contractionary Factors for Sustainable Development of the Real Estate Market by Expert Evaluation (Source: own work based on the survey)

\begin{tabular}{|c|c|c|}
\hline Level & Motivating factors & Contractionary factors \\
\hline 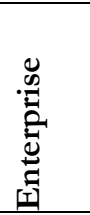 & $\begin{array}{l}\text { Financial consideration } \\
\text { Strategic management priority } \\
\text { Changes in personnel }\end{array}$ & $\begin{array}{l}\text { Failure to consider all benefits over project } \\
\text { life } \\
\text { Legal complexities } \\
\text { Financial risks }\end{array}$ \\
\hline 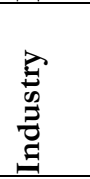 & $\begin{array}{l}\text { High operating yield } \\
\text { Increase in the number of buyers } \\
\text { Increase in investment volumes }\end{array}$ & $\begin{array}{l}\text { Lack of adequate financing models } \\
\text { Small market } \\
\text { Decrease in demand / purchasing capacity }\end{array}$ \\
\hline  & $\begin{array}{l}\text { Increase in economic activity } \\
\text { Tax policy } \\
\text { Increase in housing affordability }\end{array}$ & $\begin{array}{l}\text { Lack of consistent and long-term policy } \\
\text { frameworks } \\
\text { Tax system and tax burden } \\
\text { Policy instability and changes in legislation }\end{array}$ \\
\hline
\end{tabular}

Bureaucracy, the administrative load of the building authority, lack of labour resources, lack of responsibility, specific management problems, the aging of the housing market, social factors have been recognised by the experts as problems, because all other factors depend on the quality and condition of the society development level, the average salary funding and support (taxes), the demographic situation, political decisions, businessmen's orders to the law developers, unstable legislation, fiscal instability and imbalances, political stability, international relations, stability in the laws, raising of public awareness (clients, companies). All these factors are important and interrelated; therefore, they cannot be individually separated. The assessed PESTEL subfactors, 
which are the most important for sustainable development of the real estate market, are shown in Table 8 . Full set of factors is shown in Table 4.

Table 8. Important Subfactors of Development of the Real Estate Market and Its Evaluation by Experts (Assessment: 0 - no affect, 10 - maximum effect) (Source: own work based on the survey)

\begin{tabular}{|l|l|l|l|}
\hline Factor & Average & $\begin{array}{l}\text { Media } \\
\mathbf{n}\end{array}$ & St. dev. \\
\hline Political & 8.35 & 8 & 1.03 \\
\hline Economic & 9.03 & 9 & 0.88 \\
\hline Social & 7.79 & 8 & 1.27 \\
\hline Technological & 6.18 & 6 & 1.58 \\
\hline Environmental & 5.88 & 5 & 2.00 \\
\hline Legal & 7.82 & 8 & 3.38 \\
\hline
\end{tabular}

The development level of each PESTEL factor in the current situation according to a 10 -point scale ( 0 - not developed; 10 - perfectly developed) and the calculated factor weights according to the expert evaluation are shown in Figs. 4 and 5, respectively. The sum of all influences is equal to " 1 ".

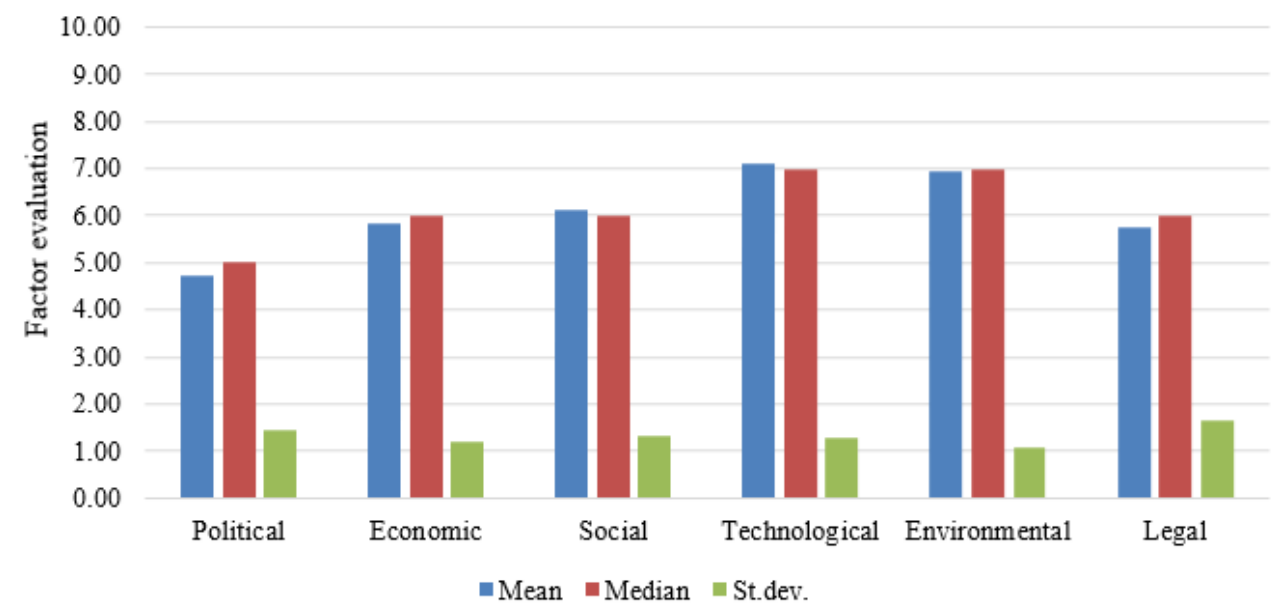

Figure 4. Development level of PESTEL factors in the current situation according to a 10-point scale (0-not developed; 10 - perfectly developed) (Source: own work based on the survey) 




Figure 5. Factor weights according to a 10-point scale (0 - not developed; 10 - perfectly developed). (Source: own work based on the survey)

The impact of environmental factors on sustainable development of the real estate market has been identified as lower than that of other indicators. It shows a problem of attitude and knowledge of environmental problems and green building sector. This may be related to the fact that this factor cannot affect the development of the real estate market immediately, for example, in comparison with economic factors, and the situation in general is evaluated as good. However, as it has been analysed in Chapters 1 and 2, taking into account the international practices, environmental factors can have a great impact on the development of the real estate market. The growth and yield indicators of the real estate market are shown in Table 9.

Table 9. Growth and Yield Indicators of the Real Estate Market (Source: own work, based on survey)

\begin{tabular}{|l|l|l|l|l|}
\hline & $\begin{array}{l}\text { Growth rate of } \\
\text { the real estate } \\
\text { market (increase } \\
\text { in price level) }\end{array}$ & $\begin{array}{l}\text { Yield (from } \\
\text { investments } \\
\text { into real estate) }\end{array}$ & $\begin{array}{l}\text { Yield } \\
\text { entrepreneurship in the real } \\
\text { estate sector) }\end{array}$ & $\begin{array}{l}\text { Yield in the } \\
\text { construction } \\
\text { sector }\end{array}$ \\
\hline Low & below 3\% & below 5\% & below $6 \%$ & below $9 \%$ \\
\hline Average & from 3\% to $7 \%$ & $\begin{array}{l}\text { from } 5 \% \text { to } \\
10 \%\end{array}$ & from 6\% to 12\% & $\begin{array}{l}\text { from } 10 \% \text { to } \\
17 \%\end{array}$ \\
\hline High & from 7\% to $10 \%$ & from $10 \%$ & from $12 \%$ & from $17 \%$ \\
\hline
\end{tabular}

At present, according to the real estate market reports, such as Colliers International (2017a; 2017b), Ober-Haus Real Estate Advisors (2017), the market growth rates can be considered average, but in some sectors - high. Such development trends and the increase in profit are also related to indicators of macroeconomic development (Kazāks, 2017).

Growth and yield indicators of the real estate market are also changing during cyclical development. By using Equations 3.4, 3.5 and 3.6, the real estate market development 
index is $0.587(58.7 \%)$ according to the results of calculations using the pair comparison method.

The assessment of the impact of factors by levels and evaluation of the current situation (the case of Latvia) are provided in Table 10.

Table 10. The Assessment of the Impact of the Factors and Current Situation by Levels, Q2 and Q3 2017 (the case of Latvia) (Source: own work based on survez)

\begin{tabular}{|l|l|l|}
\hline Level & $\begin{array}{l}\text { Influence on the Real Estate } \\
\text { Market (strong/average/low) } \\
\text { Points from 0 (min) to 100 } \\
\text { (max) }\end{array}$ & $\begin{array}{l}\text { Current } \\
\text { (positive/neutral/negative) } \\
\text { Points from 0 (min) to 100 (max) }\end{array}$ \\
\hline International & $\begin{array}{l}\text { Strong (93.75) } \\
\text { Average (6.25) } \\
\text { Low (0.00) }\end{array}$ & $\begin{array}{l}\text { Positive (7.14) } \\
\text { Neutral (28.57) } \\
\text { Negative (64.29) }\end{array}$ \\
\hline $\begin{array}{l}\text { Macroeconomic, } \\
\text { state level }\end{array}$ & Strong (89.61) & Positive (7.14) \\
& Average (9.74) & Neutral (42.86) \\
& Low (0.65) & Negative (50.00) \\
\hline Regional & Strong (56.25) & Positive (14.29) \\
& Average (37.50) & Neutral (35.71) \\
& Low (6.25) & Pegative (50.00) \\
\hline Industry & Strong (93.33) & Neutral (69.23) \\
& Average (6.67) & Negative (7.69) \\
& Low (0.00) & Individual case for each enterprise \\
\hline Enterprise & Strong (29.41) & \\
& Average (47.06) & \\
& Low (23.53) & Individual case for each household \\
& Strong (56.25) & \\
\hline Household & Average (31.25) & \\
\hline Low (12.50) & Strong (37.50) & \\
\hline & Average (43.75) & \\
& Low (18.75) & \\
\hline
\end{tabular}

As mentioned by Löwe (1928), every cycle is individual and it is required to analyse the situation in the whole system. Real estate market participants are affected by a variety of external factors and risks. The answers to the question "How often do you face the lack of information?" are provided in Figure 6. 


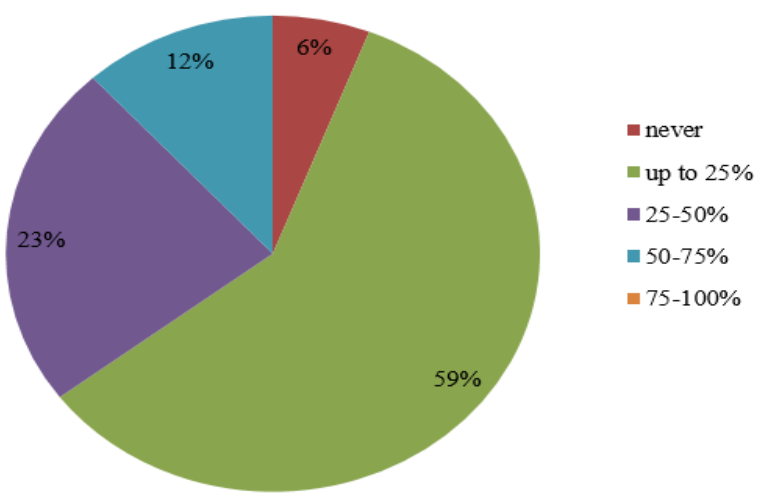

Figure 6. Respondents' responses

(Source: own work based on survey)

The international, macroeconomic and industry development has a strong influence on market participants, and, as there are a variety of risks within the industry, it is important for government and policy makers to carry out a detailed market analysis, trend identification, recession preventive activities and real estate market cooling measures. Entrepreneurs should make a detailed market analysis, focus on acquisition of profits and take preventive activities to avoid unplanned situations in some cases. Individual analysis is necessary in decision-making. The assessment of the importance of the mentioned factors for business planning in the real estate market is shown in Table 11.

Table 11. The Factors Affecting the Planning of Entrepreneurship in the Real Estate Market (Source: own work based on survey)

\begin{tabular}{|l|l|l|l|}
\hline Data & $\begin{array}{l}\text { Average } \\
\text { evaluation }\end{array}$ & Median & St.dev. \\
\hline International information & 6.53 & 7.00 & 1.79 \\
\hline $\begin{array}{l}\text { Macroeconomic indicators - GDP, inflation, world } \\
\text { economy }\end{array}$ & 7.65 & 8.00 & 1.28 \\
\hline Industry development indicators & 7.41 & 8.00 & 1.54 \\
\hline $\begin{array}{l}\text { Company's activities, demand and supply, competitor's } \\
\text { activity }\end{array}$ & 7.88 & 8.00 & 1.57 \\
\hline Contact with market participants & 7.71 & 8.00 & 1.87 \\
\hline
\end{tabular}

Influencing factors of entrepreneurship in the real estate market and their significance are shown graphically in Figure 7. 
Figure 7. Influencing Factors of Entrepreneurship in the Real Estate Market and their Significance $(\bar{x} ; 0$ - does not influence; 10 - strongly influence) (Source: own work based on survey)

The answers to the question "What knowledge and information do you lack and would like to receive for successful entrepreneurship in the framework of planning of the real estate activity?" are shown in Figure 8.

= information about project type (about project), information about specific circumstances of the project

- information about environment, in which the project is implemented,

= information on the country's development

- international factors

= information about project industry,

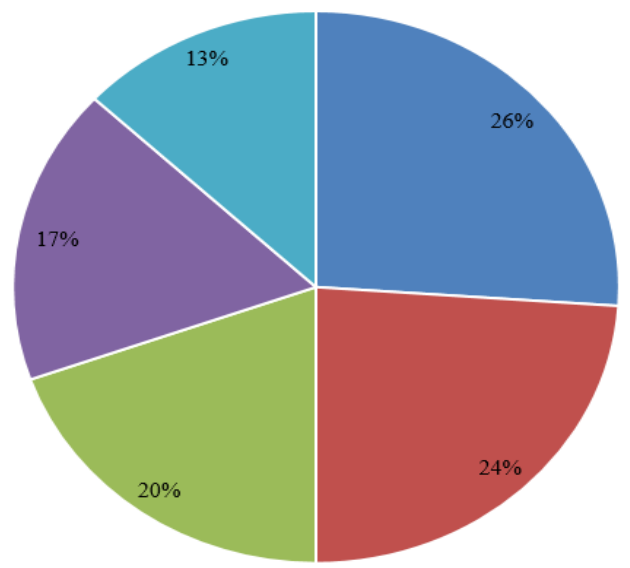

Figure 8. Respondents' responses regarding the type of information they lack (Source: own work based on survey)

The answers to the questions "Which factors should be taken into account for the reduction of risks?", "Are any informative anti-crisis measures being taken by the companies while investing?" are the following: legal requirements for non-residents, legislative peculiarities, energy efficiency and sustainability indicators for buildings. The causes for unsuccessful entrepreneurship in the Latvian real estate market (several answers are possible) are mentioned in Table 12.

Table 12. Questions Regarding the Development of the Real Estate Market (Source: own work based on survey) 


\begin{tabular}{|c|c|}
\hline Question / parameter & $\begin{array}{l}\text { Mean } \\
(10=\max )\end{array}$ \\
\hline Do you evaluate the real estate market as stable? $(0$ - not stable; 10 - very stable $)$ & 5.74 \\
\hline $\begin{array}{l}\text { Please evaluate the accuracy of the real estate market forecasts in accordance } \\
\text { with a } 10 \text { - point scale }(0-\text { not accurate; } 10 \text { - very accurate) }\end{array}$ & 5.59 \\
\hline $\begin{array}{l}\text { Please evaluate the accuracy of received information in accordance with a } 10 \text { - } \\
\text { point scale }(0-\text { not accurate; } 10 \text { - very accurate })\end{array}$ & 6.25 \\
\hline Housing affordability in Latvia (total) - expert evaluation & 5.43 \\
\hline $\begin{array}{l}\text { Is the available information optimal? Assessment } \\
\text { for the society } \\
\text { for the entrepreneurs }\end{array}$ & $\begin{array}{l}6.8 \\
7.65\end{array}$ \\
\hline $\begin{array}{l}\text { How important are the environmental factors and environment development for } \\
\text { sustainable development of the real estate market? }\end{array}$ & 7.35 \\
\hline How important is the green building certification system for you/your clients? & $\begin{array}{l}\text { Important } \\
5.88 \\
\text { Not } \\
\text { important } \\
4.12\end{array}$ \\
\hline $\begin{array}{l}\text { Do the real estate market participants have the sufficient knowledge in } \\
\text { sustainable construction? Possible answers "Yes", "No", "Partially" }\end{array}$ & $\begin{array}{l}\text { Yes }-0.00 \\
\text { No }-2.53 \\
\text { Partially } \\
7.65\end{array}$ \\
\hline
\end{tabular}

Evaluation of environmental factors plays an important role in sustainable development of the real estate market. The respondents' recommendations are as follows:

- the introduction of tax relief and simplification of the construction process of green building, work for the public sector together with the investment companies, promotion of green building by law, promotion of the state policy in this area, conclusion of the intention agreements;

- more favourable conditions are important, the material security is a key issue, additional financing is an important factor for the investments, which will bring benefit in 15-25 years, the sequence of importance according to the survey results;

- $\quad$ it is also necessary to know the costs and advantages of green building, to receive information on energy efficient solutions, to receive information about the cooperation of local government with the society and businesses, there is no structured information about green buildings and their costs, no information about the definition of concepts, lack of aggregated information from one resource on the long-term benefits and impact on health;

- $\quad$ there should be the promotion of macroeconomic stability, predictable changes (in the number of laws, tax policy, etc.), it is necessary to build qualitative and aesthetic units, while minimising the costs - both of the construction and of further maintenance of the unit, $\mathrm{m} 2$ price reduction, $\%$ reduction in the rate; the average wage increase;

- the necessity of BIM implementation, creation of the policy approach stability, the planning process rationalization, advertisements with energy performance certificates, the successful use of the European Fund, the investors' attraction, political 
decisions, the development of tourism (that can be important for the commercial sector of real estate - hotels);

- $\quad$ the sanitary-engineering provision of buildings for the units of historical type;

- $\quad$ changes in legal requirements for non-residents, the rapid changes in the law;

- $\quad$ energy efficiency problems and sustainability indicators for buildings;

- $\quad$ improvement of legal process;

- $\quad$ lack of information and difficulties in planning (difficulties in forecasts).

It has been mentioned in the replies that there is a lack of information about tax relieves and other relieves provided by green construction, about the ecological construction materials, ultimate economy, fundraising opportunities, lack of general knowledge, advertising and striving for the purest life. Sustainability can be analysed at different levels.

\section{Conclusions}

The analysis of the problems of sustainable development of the real estate market and construction industry has shown that the solution opportunities can be implemented at different (multiple) levels. The analysis includes a multi-level and complex information analysis approach and integration of political, economic, social, technological, environmental, legal and other aspects of sustainable development into analysis. In the course of the research, the real estate market and the factors affecting sustainability have been analysed in the integrated way. The approbation of the research has demonstrated that the market participants faces the lack of information. A complex approach to the analysis of the development of real estate market can positively affect the awareness of the private sector and decision-making of participants of the real estate market.

The role of the public sector is reflected in the regulation of socio-economic processes, interaction of the economy and real estate market development, as well as in the main challenges and directions of Latvia's Sustainable Development Strategy 2030. It can be recommended to introduce a separate subchapter to the stability program of country, or programs related to sustainable development of the real estate market. The concept of sustainability should be promoted at all levels and adapted to daily life as well. To solve the lack of financing mentioned as a problem by respondents, it is recommended to more actively provide information to entrepreneurs and hire additional personnel for consultation and assistance regarding renovation, infrastructure development and other possible projects.

\section{References:}

Actiņa, G. (2015). Development of Management System of Energy Efficient Processes in Latvia. Doctoral Thesis. Riga: RTU Press. 234 p.

Actiņa, G., Geipele, I., Zeltiņš, N. (2015). Planning and Managing Problems of Energy and Energy Efficiency at Regional and District Level in Latvia: Case Study. International Conference on Industrial Engineering and Operations Management (IEOM), pp. 1-7. Available at: https://doi.org/10.1109/IEOM.2015.7093843

Asaul, A. N. (2004). Real Estate Economics. St.-Petersburg: Publishing House "Piter". 512 p. 
Baccarne B., Mechant P., Schuurman D. (2014) Empowered Cities? An Analysis of the Structure and Generated Value of the Smart City Ghent. P.157-182. In: Dameri R., Rosenthal-Sabroux C. (eds) Smart City. Progress in IS. Springer, Cham. Available at: https://doi.org/10.1007/978-3-319-06160$\underline{38}$

Baltic States. Property Snapshots. Research \& Forecast Report (2017a) [online]. Colliers International [accessed on 15 August 2017]. Available at: http://www.colliers.com//media/files/emea/latvia/research/2017/colliers_baltic_quarterly_report_1q17_sec.pdf

Ben-Shahar, D., Golan, R. (2014). Real Estate and Personality. Journal of Behavioral and Experimental Economics, Vol. 53, pp.111-119. Available at: $\underline{\text { bttp:// dx.doi.org/10.1016/j.socec.2014.08.008 }}$

Binovska, I., Kauškale, L., Vanags, J. (2018). The Comparative Analysis of Real Estate Market Development Tendencies in Baltic States. Baltic Journal of Real Estate Economics and Construction Management, Vol. 6. Iss. 1, p. 6-23. doi: 10.1515/bjreecm-2018-0001

Brauers, W.K., Lepkova, N. (2003). The Application of the Nominal Group Technique to the Business Outlook of the Facility Sector of Lithuania over the Period 2003-2012. International Journal of Strategic Property Management, Vol. 7 Iss. 1, pp.1-9.

Economy Rankings [online]. Doing Business [accessed on November 20, 2017]. Available at: http:// www. doingbusiness.org/rankings

Energy Efficiency in Buildings - Action Plan (2015) [online]. WBCSD Publication Library [accessed on 5 January 2016]. Available at: bttp:// wbcsdpublications.org/project/energy-efficiency-in-buildings-action-plan/

Energy Efficiency in Buildings 2.0 (n.d.) [online]. WBCSD Publication Library [accessed on 5 January 2016].

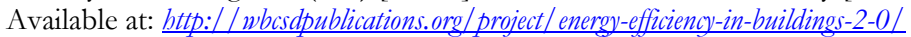

Erzah, L. (2011). Difference between a Brainstorm and Focus Group [online]. Modern Analyst Media LLC. [accessed on 3 September 2017]. Available at: http:// www.modernanalyst.com/Community/CommunityBlog/tabid/182/ID/1904/Difference-between-aBrainstorm-and-Focus-Group.aspx

Galbraith, J.K. (1958) The Affluent Society, as cited in Vilks, A. (2007). Pasaules Sociologi (World Sociologists). Riga: „Drukatava”. 156 p.

Gallagher, M., Hares, T., Spencer, J., Bradshaw, C., Webb, I. (1993). The Nominal Group Technique: A Research Tool for General Practice? Family Practice, Vol.10 Iss.1, pp. 76-81.

Gan, X., Fernandez, I.C., Guo, J., Wilson, M., Zhao, Y., Zhou, B., Wu, J. (2017). When to Use What: Methods for Weighting and Aggregating Sustainability Indicators. Ecological Indicators, Vol. 81, pp. 491-Statistisches Bundeamt502. Available at: https://doi.org/10.1016/j.ecolind.2017.05.068

Geipele, I., Kauškale, L., Lepkova, N., Liias, R. (2014). Interaction of Socio-Economic Factors and Real Estate Market in the Context of Sustainable Urban Development. In: 9th International Conference on Environmental Engineering (ICEE-2014): Selected Papers, Lithuania, Vilnius, 2224 May, 2014. Vilnius: Vilnius Gediminas Technical University Press Technika, 2014, pp.1-8. ISBN 978-609-457-640-9. e-ISBN 978-609-457-690-4. e-ISSN 2029-7092. Available at: doi:10.3846/enviro.2014.117 Thomson Reuters, Scopus

Geo5 Global Environmental Outlook. Environment for the Future We Want (2012) [online]. UNEP (United Nations Environment Programme). Malta: Progress Press Ltd. [accessed on 5 October 2016]. Available at: http:/ / wmw.unep.org/geo/sites/unep.org.geo/files/documents/geo5 report c11.pdf

Guo, L., Ma, H. (2008). Conflict between Developing Economic and Protecting Environment. Journal of Sustainable Development, Vol. 1. Iss. 3. Available at: http:/ / wnw.ccsenet.org/journal/ index.php/jsd/article/viewFile/1229/1119

Hatemi-J, A., Roca, E., Al-Shayeb, A. (2014). How Integrated are Real Estate Markets with the World Market? Evidence from Case-Wise Bootstrap Analysis. Economic Modelling, Vol. 37, pp. 137142.

Hines, M.A. (2001). Investing in International Real Estate. Westport, Conn, London: Quorum Books, 293 p. Hoppe, M.J., Wells, E.A., Morrison, D.M., Gilmore, M.R., Wilsdon, A. (1995). Using Focus Groups to Discuss Sensitive Topics with Children. Evaluation Review 19 (1): 102-14, as cited in Gibbs, A. (1997). Focus Groups. Available at: http:// sru.soc.surrey.ac.uk/SRU19.html

Hui, E. C-M., Wang, Z. (2015). Can we Predict the Property Cycle? A Study of Securitized Property Market. Physica A, Vol. 426, pp.72-87, 2015. Available at: http://dx.doi.org/10.1016/j.physa.2015.01.013

Hui, E.C.M., Chan, K.K. (2014). Foreign Direct Investment in China's Real Estate Market. Habitat International, Vol. 43, pp. 231-239. 
Kauškale, L., Geipele, I. (2015b). Foreign Direct Real Estate Investments in Latvia in the Context of the Development of the National Economy. In: Economic Science for Rural Development, No.37: 16th International Scientific Conference "Economic Science for Rural Development", Latvia, Jelgava, 23-24 April, 2015. Jelgava: Latvia University of Agriculture, 2015, pp.241-250. ISBN 9789984-48-180-7. ISSN 1694-3078. e-ISSN 2255-9930. Thomson Reuters, WOS:000360011300024

Kauškale, L., Geipele, I. (2016a). Economic and Social Sustainability of Real Estate Market and Problems of Economic Development - A Historical Overview. Baltic Journal of Real Estate Economics and Construction Management, 3, p.2255-9671, DOI: 10.1515/bjreecm-2016-0002. EBSCO

Kauškale, L., Geipele, I. (2016b). Economic Problems of Real Estate Market and Its Influence on the Development of Business Environment. In: Proceedings of the 2016 International Conference “Economic Science for Rural Development”. No.43, Latvia, Jelgava, 21-22 April, 2016. Jelgava: 2016, pp.39-48. ISBN 978-9984-48-225-5. ISSN 1691-3078. Thomson Reuters WOS:000391253200004

Kauškale, L., Geipele, I. (2016c). Influence of Economic and Real Estate Market Fluctuations on Real Estate Entrepreneurship in Latvia. In: Proceedings of the Sixth International Conference on Industrial Engineering and Operations Management, Malaysia, Kuala Lumpur, 8-10 March, 2016. Kuala Lumpur: 2016, pp.851-862. ISBN 978-0-9855497-4-9. ISSN 2169-8767. Scopus. Code 135628.

Kauškale, L., Geipele, I. (2017). Integrated Approach of Real Estate Market Analysis in Sustainable Development Context for Decision Making. Procedia Engineering, 2017, Vol.172, pp.505-512. ISSN 1877-7058. Available from: doi:10.1016/j.proeng.2017.02.059 Scopus, ISI Wos.

Kauškale, L., Geipele, I., Zeltiņš, N., Lecis, I. (2017). Environmental and Energy Aspects of Construction Industry and Green Buildings. Latvian Journal of Physics and Technical Sciences, 2017, Vol.54, No.2, pp.24-33. ISSN 0868-8257. Available at: doi:10.1515/lpts-2017-0010 Scopus.

Kazāks, M. (2017). Jaunākā Swedbank ekonomikas apskata prezentācija [A Presentation of the Latest Swedbank Economic Overview [online]. Available at: https:// www.facebook.com/SwedbankLLatvia/videos/1782591198417832

Koetter, M., Poghosyan, T. (2010). Real Estate Prices and Bank Stability. Journal of Banking \& Finance, Vol. 34, pp. 1129-1138. Available at: doi:10.1016/j.jbankfin.2009.11.010

Kuang, P. (2014). A Model of Housing and Credit Cycles with Imperfect Market Knowledge. European Economic Review, Vol. 70, pp. 419-437. Available at: bttp://dx.doi.org/10.1016/j.euroecorev.2014.06.013

Kuznets, S. (1955). Economic Growth and Income Inequality [online]. The American Economic Review, Vol. 45 Iss. 1. American Economic Association [accessed on 14 November 2015]. Available at: https:// www.aeaweb.org/aer/top20/45.1.1-28.pdf

Kvalitatīvās pētijumu metodes [Qualitative Research Methods] (2012) [online]. Public process research center [accessed on 30 August 2017]. Available at: http:/ /www.petijumi.lv/kvalitativas-izpetes-metodes/

Lapigin, Y., Lapigin, D. (2009). Upravlencheskie reshenija [Management Decisions]. Moskva: Eksmo. 448 p.

Li, L., Li, G., Zhou, Y. (2015). Do Securitized Real Estate Markets Jump? International Evidence. PacificBasin Finance Journal, Vol. 31, pp. 13-35. Available at: http://dx.doi.org/10.1016/j.pacfin.2014.11.001

Linton, J. (2005). Focus Groups, Brainstorming Sessions, and Large Group Planning Workshops [online]. TCI Management Consultants [accessed on 15 September 2017]. Available at: http:// www.consulttci.com/Resource material/Focusgroups.pdf

Löwe. A. (1928). Über den Einfluß monetärer Faktoren auf den Konjukturzyklus [On the Influence of Monetary factors on the Conjugate Cycle]. Beiträge zur Wirtschaftstheorie. Zweiter Teil: Konjukturforschung und Konjukturtheorie [Contributions to Business Theory. Second Part: Conjuction Research and Theory]. Edited by K. Diehl. Schriten des Vereins für Sozialpolitik [Publications of the Association for Social Policy]. 173/II. Münich: Duncker und Humblot, pp. 355-370, as cited in Glasner, D., Cooley, T.F. (1997). Business Cycles and Depressions: An Encyclopedia (Garland Reference Library of Social Science). 1st edition. New York: Garland Pub. $796 \mathrm{p}$.

Lu, W., Peng, Y., Webster, C., Zuo, J. (2015). Stakeholders' Willingness to Pay for Enhanced Construction Waste Management: A Hong Kong study. Renewable and Sustainable Energy Reviews, Vol. 47, pp. 233-240. Available at: http:// dx.doi.org/10.1016/j.rser.2015.03.008 
Manders, T., Chateau, J., Magné, B., Vuuren, D, Gerdien Prins, A., Dellink, R. (2012). OECD Environmental Outlook to 2050 [online]. OECD Publishing [accessed on 16 March 2016]. Available at: http://www.oecd-ilibrary.org/environment/oecd-environmental-outlook-to2050/socio-economic-developments_env_outlook-2012-5-en

Marczak, M., Sewell, M. (n.d.) Using Focus Groups for Evaluation [online]. The University of Arizona. College of Agriculture \& Life Sciences [accessed on 5 September 2017]. Available at: bttps://cals.arizona.edu/sfcs/cyfernet/cyfar/focus. btm

Maxwell, J.A. (2005). Qualitative Research Design: An Interactive Approach [online]. Sage Publishing [accessed on 30 August 2017]. Available at: http:// www.sagepub.in/upm-data/23772 Ch7.pdf

Mayring, P. (2010). Qualitative Content Analysis. Fundamental Principles and Approaches. [Qualitative Inhaltsanalyse. Grundlagen und Techniken]. 11., aktualisierte und überarbeitete Auflage [11 th updated and revised edition]. Weinheim und Basel: Beltz Verlag [Beltz Publishing House]. 144 p. ISBN 978-3-40725533-4.

Menger, C. (1871). Principles of Economics. Translated by J. Dingwall and B. F. Hoselitz, with an introduction by Friedrich A. Hayek. New York: New York University Press. USA: Ludwig von Mises Institute. Available at: http:// mises.org/document/595

Module 9: Introduction to Research (n.d.) [online]. University of Surrey [accessed on 10 September 2017]. Available

at: http:// libweb.surrey.ac.uke/library/skills/Introduction\%20to\%20Researcb\%20and\%20Managing\%20Informati on\%20Leicester/page $54 . \mathrm{htm}$

Ober-Haus Real Estate Advisors. (2017). Real Estate Market Report Baltic States 2017. Baltic States Capitals: Vilnius, Riga, Tallinn. [accessed on 27 April 2017]. Retrieved from Ober-Haus Real Estate Advisors webpage. Available at: http://wmw.ober-haus.lv/wp-content/uploads/2017/03/Ober-HausMarket-Report-Baltic-States-2017.pdf

Peiser, R.B., Frei, A. (2005). Professional Real Estate Development: the ULI Guide to the Business. 2nd ed. Washington: The Urban Land Institute. 397 p. ISBN 0874208947

Peterson, K. Gammill, R. (2010). The Economics of Sustainability in Commercial Real Estate [online]. IFMA 38 p. [accessed on 5 December 2015]. Available at: https://foundation.ifma.org/docs/defaultsource/Whitepapers/foundation-economics-of-sustainability-in-commercial-real-estate.pdf?sfursn $=2$

Pollesch, N., Dale, V., (2015). Applications of Aggregation Theory to Sustainability Assessment. Ecological Economics, Vol. 114, pp. 117-127. Available at: https:// doi.org/10.1016/j.ecolecon.2015.03.011

Powell, R.A., Single, H.M. (1996). Focus Groups. International Journal of Quality in Health Care, Vol. 8 Iss. 5, pp.499-504, as cited in Gibbs, A. (1997). Focus Groups. Available at: http://sru.soc.surrey.ac.uk/SRU19.html

Rogmans, T., Ghunaim, M. (2016). A Framework for Evaluating Sustainability Indicators in the Real Estate Industry. Ecological Indicators, Vol. 66, pp. 603-611. doi: 10.1016/j.ecolind.2016.01.058

Schwab, K. (2016). The Global Competitiveness Report 2016-2017. World Economic Forum. Available at: bttps:// wnw.weforum.org/ reports/ the-global-competitivenessreport-2016-2017-1

Statistical classification of economic activities in the European Community (2006) [online]. European Commission $\left.\begin{array}{llllll}\text { [accessed } & \text { on } & 8 & \text { February } & 2018\end{array}\right]$ Available bttp:// ec.europa.eu/ eurostat/documents/3859598/5902521/KS-RA-07-015-EN.PDF

Štaube, T., Leemeijer, B., Geipele, S., Kauškale, L., Geipele, I., Jansen, J. (2016). Economic and Financial Rationale for Age-Friendly Housing. Journal of Financial Management of Property and Construction, 2016, Vol.21 Iss.2, pp.99-121. ISSN 1366-4387. Available at: doi:10.1108/JFMPC05-2015-0015 Scopus, Thomson Reuters

Van de Ven, A.H., Delbecq A.L. (1972). The Nominal Group as a Research Instrument for Exploratory Health Studies. American Journal of Public Health, March, pp. 337-342.

Wofford L.E., Clauretie, T.M. (1992). Real Estate. 3rd edition. 688 p. ISBN 0-471-54848-0. 


\section{AUTHORS' SHORT BIOGRAPHIES}

Linda Kauškale, Mg. oec., is a researcher, lecturer, and an assistant researcher of the Institute of Civil Engineering and Real Estate Economics, Faculty of Engineering Economics and Management, Riga Technical

University. She with distinction obtained Professional Master Degree in Civil Construction and Real Estate Management, has the qualification of Real Estate Economist and extensive practical experience. She has participated in international scientific conferences and seminars in Latvia, Germany, United Arab Emirates, Singapore, Malaysia, Lithuania etc. Her main research areas are sustainable real estate market concept, sustainable cities and sustainable construction, green buildings, macroeconomic analysis, business cycle, decision-making, environmental development problems, etc. She is DGNB (Deutsche Gesellschaft für nachhaltiges Bauen - German Sustainable Building Council) Registered Professional. In year 2016 she was a Professional Member of Industrial Engineering and Operations Management Society. In autumn 2016, she was Deutsche Bundesstiftung Umwelt (German Environmental Foundation) Scholarship holder. In autumn 2013, she was a FIABCI scholar.

ORCID iD: http://orcid.org/0000-0002-0280-2977

Ineta Geipele is a Professor of the Faculty of Engineering Economics and Management, Director of the Institute of Civil Engineering and Real Estate Economics, the Head of the Department of the Civil Construction and Real

Estate Economics and Management at Riga Technical University, Latvia. She improved her professional skills in Austria, Germany, Denmark and the UK. Ineta Geipele is the author and co-author of more than 300 scientific

publications. Her current research areas are sustainability development problems of real estate market, construction industry, land use management and institutional economics. Professor Ineta Geipele is an expert of the Latvian Academy of Sciences in Management and Economics Sciences at the Latvian Council of Science, a board member of the FIABCI-Baltic Multinational Chapter and of the Cunfte of the Facility Management of Latvian Housing, and a member of the Latvian Union of Civil Engineers.

ORCID iD: http://orcid.org/0000-0002-2963-087X 